\title{
An Electrochemical Sensing Platform Based on Iridium Oxide for Highly Sensitive and Selective Detection of Nitrite and Ascorbic Acid
}

\author{
Totka Dodevska, ${ }^{\star}$ Ivan Shterev and Yanna Lazarova \\ Department of Organic Chemistry and Inorganic Chemistry, University of Food Technologies, 26, Maritsa Boulevard, \\ Plovdiv 4002, Bulgaria \\ * Corresponding author: E-mail: dodevska@mail.bg \\ Tel.: +35932603 679; Fax: +35932644102
}

Received: 10-08-2018

\begin{abstract}
Iridium oxide $\left(\mathrm{IrO}_{\mathrm{x}}\right)$ was electrodeposited onto glassy carbon electrode applying two-step potential cycling procedure. The electrocatalytic properties of the modified electrode $\mathrm{IrO}_{\mathrm{x}} / \mathrm{GC}$ were evaluated with regards to electrochemical oxidation of nitrite and ascorbic acid (AA). The developed electrode-catalyst have been extensively studied by various electrochemical techniques. Differential pulse voltammetry (DPV) experiments indicated that the modified electrode possesses excellent electrocatalytic activity towards the oxidation of both nitrite and AA in neutral medium and offers simultaneous quantification of these substances. Constant potential amperometry studies also were performed - the $\mathrm{IrO}_{\mathrm{x}} /$ GC showed sensitive response to nitrite $\left(159.7 \mu \mathrm{A} \mathrm{mM}^{-1} \mathrm{~cm}^{-2}\right)$ with a wide linear range from 0.002 to $10 \mathrm{mM}$ at $0.77 \mathrm{~V}$ (vs. $\mathrm{Ag} / \mathrm{AgCl}, 3 \mathrm{M} \mathrm{KCl}$ ), and to $\mathrm{AA}\left(96.2 \mu \mathrm{A} \mathrm{mM} \mathrm{mm}^{-1} \mathrm{~cm}^{-2}\right)$ with a linear range from 0.01 to $3 \mathrm{mM}$ at $0.025 \mathrm{~V}$. The detection limit was $0.63 \mu \mathrm{M}$ nitrite and $4 \mu \mathrm{M}$ AA, respectively, and both of them had fast response within $5 \mathrm{~s}$. Considering the simple and rapid electrodeposition procedure for preparation, $\mathrm{IrO}_{\mathrm{x}} / \mathrm{GC}$ is a new electrode-catalyst for sensitive and selective quantitative detection of nitrite and AA. The wide linear range, good selectivity, reproducibility of the amperometric response and long-time stability of the $\mathrm{IrO}_{\mathrm{x}} / \mathrm{GC}$ make it a promising sensing material for practical nonenzymatic quantitative detection of nitrite and AA.
\end{abstract}

Keywords: Electrochemistry; electrocatalytic oxidation; sensor; nitrite; ascorbic acid

\section{Introduction}

Nitrite $\left(\mathrm{NO}_{2}^{-}\right)$is widely used food additive in meat products as an antimicrobial agent (prevents bacterial growth), a preservative (retards lipid peroxidation) and a color fixative. ${ }^{1}$ Nitrate also has been found in beverages, commercially available vegetables and drinking water. The concentration of $\mathrm{NO}_{2}^{-}$is one of the most important parameters in water quality - the World Health Organization (WHO) recommends a guideline value of $3 \mathrm{mg} \mathrm{L}^{-1}(65 \mu \mathrm{M})$ and a provisional guideline value of $0.2 \mathrm{mg} \mathrm{L}^{-1}(4.3 \mu \mathrm{M})$ for short-term and long-term exposures, respectively; ${ }^{2,3}$ according to the regulation of the European Community the maximum permissible nitrite content in drinking water is $0.1 \mathrm{mg}$ $\left.\mathrm{L}^{-1}(2.2 \mu \mathrm{M})\right)^{4,5} \mathrm{~A}$ serious threat to human health is the overweight content of nitrite in food products, as the excessive ingestion of nitrites via the dietary intake has potential toxic and mutagenic effects. Nitrite consumption has been linked with chronic obstructive pulmonary disease, ${ }^{6}$ methemoglo- binemia ${ }^{7}$ - nitrite interacts with the hemoglobin $\left(\mathrm{Fe}^{2+}\right)$ to form methemoglobin $\left(\mathrm{Fe}^{3+}\right)$ which has no oxygen carrying ability, gastric and oesophageal cancer ${ }^{8}-$ nitrite ion is an essential precursor in the formation of highly carcinogenic nitrosamines in the stomach. The acceptable daily intake of nitrite is $0-0.07 \mathrm{mg} \mathrm{kg}^{-1}$ (body weight) per day. ${ }^{9}$

Classical analytical techniques have been employed for quantitative detection of nitrite such as coulometric titration, ${ }^{10}$ spectrofotometry, ${ }^{11}$ chemiluminescence, ${ }^{12}$ capillary electroforesis, ${ }^{13}$ high-performance liquid chromatography. ${ }^{14}$ Most of these analytical methods, however, require complex painstaking procedures for sample pre-treatment, as well as involve fairly expensive and sophisticated instruments. Therefore, the importance of improved analytical methods for determination of nitrite has received considerable attention.

Nitrite ion is an electroactive and can be quantified electrochemically. In comparison with the aforementioned techniques, electrochemical analysis has been considered 
as a low-cost and effective way due to its intrinsic simplicity and high sensitivity. The electrochemical sensor devices provide the opportunity for an accurate, sensitive, selective, interference-free, fast, cost-effective and susceptible to automation analysis, and are a promising alternative of the traditional analytical techniques.

The electrochemical determination of nitrite can be realized based on oxidation or reduction, as oxidation is usually preferred because cathodic measurement is prone to interference from other easily reducible species such as nitrate ion (product of nitrite reduction) and molecular oxygen. At the same time detection based on the oxidation of nitrite offers some advantages, such as no interference from nitrate ion, sulfate ion, and molecular oxygen. Nitrite can be oxidased at conventional electrode - bare glassy carbon (GC), platinum or gold electrodes, but the direct electrooxidation of nitrite ions requires high overpotential at the surface of the unmodified electrode and quantification suffers from interference from other compounds. The process is accompanied by co-oxidation of interfering species that present in the real samples. As a result, the registered signal is higher and does not correspond to the real concentration of the analyte.

In order to improve the oxidation response of $\mathrm{NO}_{2}{ }^{-}$ (resp., the selectivity of detection), the applied potential should be efficiently lowered. This can be achieved by modifying the surface of the bare electrode with suitable electrocatalytic active phase, that facilitates electron-transfer process - conducting polymer films, ${ }^{15-22}$ metal particles decorated polymers, ${ }^{3,23,24}$ metal complexes, ${ }^{25-27}$ metal-organic frameworks, ${ }^{28}$ metal or metal oxide patricles, ${ }^{29-35}$ bimetallic nanomaterials, ${ }^{36}$ ionic liquid, ${ }^{29,37}$ methylene blue, ${ }^{38}$ chemically reduced graphene oxide. ${ }^{39}$

One of the main interfering substances in the quantitative detection of nitrite in food samples is ascorbic acid. Ascorbic acid (AA), also known as vitamin $\mathrm{C}$, is one of the most important vitamins that takes part in some important biological reactions such as free radical scavenging and cancer preventing. This compound exists in plant, especially fresh fruits and leafy vegetables, and animal tissues. The strong antioxidant activity of AA and its ability to protect oxidizable constituents, including phenolic and flavor compounds, is the main factor AA to be frequently used in food industry to prevent unwanted changes in color or flavor. Additives, based on AA, are widely used in production of several foods and drinks such as beer, jam, sweets, fruit juices, fish products and meats. AA is used as well as in cosmetics (as a skin conditioning agent) and in pharmaceutical industry (as a diet supplement in various forms). Side effects are not observed at normal AA intake (about 70-90 mg for adults), ${ }^{40}$ due to the fact that it is water soluble and quickly excreted. After single oral doses of vitaminin $\mathrm{C}$ greater than $2 \mathrm{~g}$ daily, gastrointestinal distress and diarrhea are the most common side effects. However, in individuals with renal disfunction, production of kidney stones is observed as a serious side effect with vitaminin C overdose. Due to the crucial role of AA in biochemistry and in industrial applications, recently there is a considerable research interest to develop electrochemical sensors for detection of AA content in various samples including foods, drugs and biological fluids. ${ }^{40-51}$

Among the above-mentioned modified electrodes-catalysts applied for nitrite detection, metal oxide-modified electrodes possess some unique electrochemical properties and advantages compared to the other - high stability, enhancement of reaction rate due to the redox couples of oxide species of two different states, as well as weak adsorption or exclusion of hydrogen species on an oxide surface. ${ }^{31}$ Because of the high electron transfer rate constant of $\mathrm{Ir}(\mathrm{IV}) / \mathrm{Ir}$ (III) redox couple, $\mathrm{IrO}_{\mathrm{x}}$ were used as an electron transfer mediator and successfully applied in electrocatalysis. ${ }^{52-55}$ The present research reports an amperometric sensor for nitrite and AA detection, based on modified with iridium oxide GC electrode. As an electrode material, GC is distinguished by its chemical inertness, low background currents, wide potential window and low price. Cyclic voltammetry (CV) was applied to form iridium oxide layers at the surface of the bare GC electrode as the fastest and simplest electrodeposition technique, that not requires expensive equipment or special experimental conditions (high temperature and pressure). The developed electrode exhibits remarkable electrocatalytic activity in two independent electrocatalytic processes - oxidation of nitrite (at an applied potential of $0.77 \mathrm{~V}$ vs. $\mathrm{Ag} / \mathrm{AgCl}, 3 \mathrm{M} \mathrm{KCl}$ ) and oxidation of $\mathrm{AA}$ (at $0.025 \mathrm{~V}$ ) and offers simultaneous quantification of both substances. The modified electrode has advantages such as high sensitivity in a relatively wide range of substrate concentrations, selectivity, excellent reproducibility of the current signal and long-term stability.

\section{Experimental}

\section{1. Materials}

$\mathrm{Na}_{2} \mathrm{IrCl}_{6}, \mathrm{HCl}, \mathrm{H}_{2} \mathrm{SO}_{4}, \mathrm{NaOH}, \mathrm{NaNO}_{2}, \mathrm{NaNO}_{3}$, $\mathrm{NaOOCCH}_{3}, \mathrm{NaCl}, \mathrm{Na}_{2} \mathrm{CO}_{3}, \mathrm{KCl}, \mathrm{KBr}, \mathrm{KBrO}_{3}, \mathrm{KI}, \mathrm{MgCl}_{2}$, $\mathrm{CuSO}_{4}$ were purchased from Fluka; $\mathrm{Na}_{2} \mathrm{HPO}_{4} 12 \mathrm{H}_{2} \mathrm{O}$, $\mathrm{NaH}_{2} \mathrm{PO}_{4} \quad 2 \mathrm{H}_{2} \mathrm{O}, \mathrm{K}_{3}\left[\mathrm{Fe}(\mathrm{CN})_{6}\right]$, sodium citrate $(\mathrm{Na}-$ $\left.{ }_{3} \mathrm{C}_{6} \mathrm{H}_{5} \mathrm{O}_{7}\right)$, ascorbic acid $\left(\mathrm{C}_{6} \mathrm{H}_{8} \mathrm{O}_{6}\right)$ and glucose $\left(\mathrm{C}_{6} \mathrm{H}_{12} \mathrm{O}_{6}\right)$ were purchased from Sigma-Aldrich. All chemicals used were of analytical grade and double distilled water was used to prepare aqueous solutions. Buffer solution, $0.1 \mathrm{M}$, was made of monobasic and dibasic sodium phosphates dissolved in double distilled water with $\mathrm{pH} 7.0$ adjusted with $\mathrm{NaOH}$. The working electrode was a disc $(3 \mathrm{~mm}$ diameter) from glassy carbon rod (Metrohm) in Teflon holder.

\section{2. Apparatus and Measurements}

All the electrochemical measurements were performed using potentiostat EmStat2 (PalmSens BV, The 
Netherlands) interfaced with a computer and controlled by 'PSTrace 2.5.2' software. A conventional thermostated three-electrode cell including a working electrode, an Ag/ $\mathrm{AgCl}(3 \mathrm{M} \mathrm{KCl})$ as a reference electrode, and a platinum wire as a counter electrode was used. Before the measurement the background electrolyte was purged with pure argon for at least $15 \mathrm{~min}$ to remove dissolved oxygen. The modified electrode was investigated using cyclic voltammetry $(\mathrm{CV})$, differential pulse voltammetry (DPV) and amperometry at a constant potential. Cyclic voltammograms (CVs) were recorded at scan rates from 10 to 150 $\mathrm{mV} \mathrm{s}^{-1}$. The DPV parameters were chosen as follows: scan rate $9 \mathrm{mV} \mathrm{s}^{-1}$, pulse amplitude $50 \mathrm{mV}$, pulse interval $70 \mathrm{~ms}$. Amperometric (i-t) curves were monitored at a constant applied potential under hydrodynamic condition. The experimental data analysis was performed using software package 'OriginPro 8.0'.

\section{3. Electrodeposition of Iridium Oxide onto Glassy Carbon Electrode}

Prior to the modification, the glassy carbon electrode surface was polished mechanically using $0.05 \mu \mathrm{m}$ alumina slurry, rinsed, sonicated in double distilled water for $5 \mathrm{~min}$ and allowed to dry at room temperature. The electrodeposition of $\mathrm{IrO}_{\mathrm{x}}$ onto the GC electrode was carry out in two-step procedure as follows: deposition of iridium from $2.0 \% \mathrm{Na}_{2} \mathrm{IrCl}_{6}$ in $0.1 \mathrm{M} \mathrm{HCl}$ solution using $\mathrm{CV}$ from -0.3 to $0.3 \mathrm{~V}$ applying 100 cycles at scan rate of $100 \mathrm{mV} \mathrm{s}^{-1}$ and subsequent oxidation of iridium applying 100 cycles from -0.3 to $1.4 \mathrm{~V}$ in electrolyte $0.5 \mathrm{M} \mathrm{H}_{2} \mathrm{SO}_{4} \cdot{ }^{55}$

\section{Results and Discussion}

\section{1. Electrochemical Behavior of $\mathrm{IrO}_{\mathrm{x}} / \mathrm{GC}$ Modified Electrode}

The electrochemical behavior of the $\mathrm{IrO}_{\mathrm{x}} / \mathrm{GC}$ modified electrode was investigated by cyclic voltammetry. The

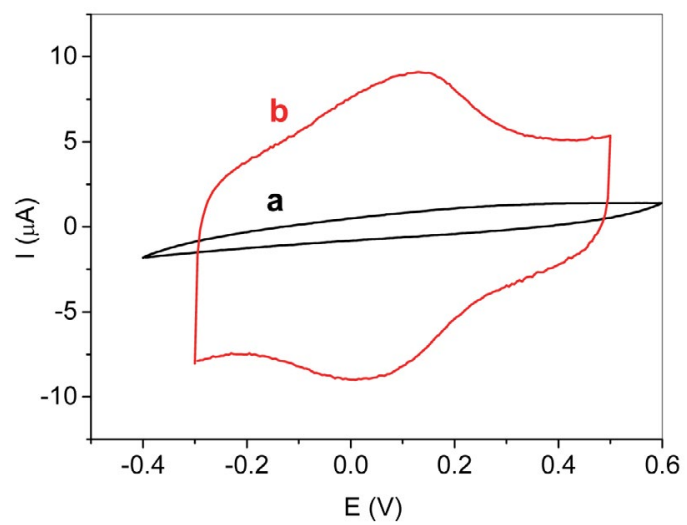

Fig. 1. CVs of the bare GC electrode (curve a) and $\mathrm{IrO}_{\mathrm{x}} / \mathrm{GC}$ modified electrode (curve b) in PBS, $\mathrm{pH} 7.0$, recorded at scan rate of $50 \mathrm{mV} \mathrm{s}^{-1}$. cyclic voltammograms of the bare GC electrode and $\mathrm{IrO}_{\mathrm{x}} /$ GC modified electrode registered in PBS pH 7.0 are shown in Fig. 1. Compared with the bare GC electrode (curve a), the background current of the modified electrode is apparently larger, which indicates that the effective electrode surface area is significantly enhanced (curve b). The pair of well-defined redox peaks at $0.13 \mathrm{~V}$ and $0.02 \mathrm{~V}$, respectively, assigned to the redox couple $\operatorname{Ir}(\mathrm{III}) / \mathrm{Ir}(\mathrm{IV})$, proves the successful modification of the electrode surface.

For the evaluation of the electrochemically active surface area of the modified electrode, cyclic voltammograms were registered at different scan rates using $\left[\mathrm{Fe}(\mathrm{CN})_{6}\right]^{3-14-}$ in $0.1 \mathrm{M} \mathrm{KCl}$ as a redox probe. The data confirm that the $\mathrm{IrO}_{\mathrm{x}}$-deposit favors the electron transfer rate of the redox probe. A noticeable enhancement in the peak magnitude accompanied with decreased peak potential separation $\left(\Delta \mathrm{E}_{\mathrm{p}}\right)$ were observed after the modification of bare GC, which indicated that the $\mathrm{IrO}_{\mathrm{x}}$-deposit could enhance the effective surface area and the conductivity of the electrode.

For the single electron transfer of $\mathrm{Fe}^{3+} / \mathrm{Fe}^{4+}$ redox reaction at a scan rate of $50 \mathrm{mV} \mathrm{s}^{-1}$ for $\mathrm{IrO}_{\mathrm{x}} / \mathrm{GC}$ modified electrode was determinated peak potential separation $\Delta \mathrm{E}_{\mathrm{p}}$ $=0.09 \mathrm{~V}$, which is $0.07 \mathrm{~V}$ lower than that of the bare GC electrode $\left(\Delta \mathrm{E}_{\mathrm{p}}=0.16 \mathrm{~V}\right)$. A linear dependence was obtained between the peak currents and the square root of the scan rate, demonstrating that the redox process of ferri/ferrocyanide at the modified electrode surface is diffusion controlled (Fig. 2). The electro-active surface area was estimated according to Randles-Ševćik equation:

$$
I_{p}=0.4463\left(F^{3} / R T\right)^{1 / 2} n^{3 / 2} A_{0} D_{0}^{1 / 2} C_{0} v^{1 / 2}
$$

where $I_{p}$ is the peak current $(A), v$ is the applied scan rate $\left(\mathrm{V} \mathrm{s}^{-1}\right), \mathrm{n}=1$ (number of electrons involved in the redox reaction), $A_{0}$ is the electrode surface area $\left(\mathrm{cm}^{2}\right), D_{0}$ is diffusion coefficient $\left(D_{0}=7.6 \times 10^{-6} \mathrm{~cm}^{2} \mathrm{~s}^{-1}\right), \mathrm{C}_{0}$ is the bulk concentration of the substrate $\left(\mathrm{C}_{0}=5 \times 10^{-3} \mathrm{M}\right)$. In this system, the slope is 243.94 , taking temperature $\mathrm{T}=298 \mathrm{~K}$, molar gas constant $\mathrm{R}=8.314 \mathrm{~J} \mathrm{~K}^{-1} \mathrm{~mol}^{-1}$, and Faraday's

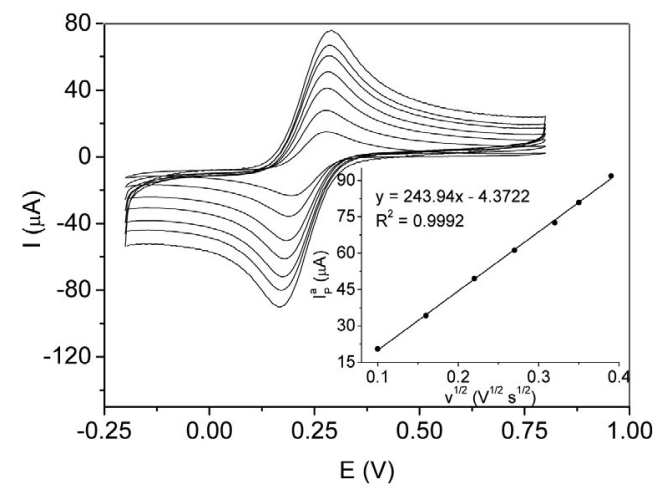

Fig. 2. CVs of modified electrode $\mathrm{IrO}_{\mathrm{x}} / \mathrm{GC}$ in presense of $5 \mathrm{mM}$ of $\mathrm{K}_{3}\left[\mathrm{Fe}(\mathrm{CN})_{6}\right]$ in $0.1 \mathrm{M} \mathrm{KCl}$ solution registered at different scan rates $\left(10-150 \mathrm{mV} \mathrm{s}^{-1}\right)$. Inset: plot of anodic peak current vs. $\mathrm{v}^{1 / 2}$. 
constant $\mathrm{F}=96480 \mathrm{C} \mathrm{mol}^{-1}$, the effective surface area was calculated to be $0.065 \mathrm{~cm}^{2}$. Compared with the bare GC electrode $\left(0.036 \mathrm{~cm}^{2}\right.$, calculated analogously), the electroactive surface area of the $\mathrm{IrO}_{\mathrm{x}} / \mathrm{GC}$ modified electrode was increased by approximately $80 \%$.

\section{2. Electrocatalytic Oxidation of Nitrite and Ascorbic Acid}

To study the application of the modified electrode $\mathrm{IrO}_{\mathrm{x}} / \mathrm{GC}$ in electrochemical sensing of nitrite and AA, electrooxidation and quantitative detection of these substances in neutral medium were investigated. The performance of the modified electrode regarding the sensing of each of the substances was evaluated using two electrochemical techniques - DPV and constant potential amperometry, according to the sensitivity, linear range, detection limit, and stability.

DPV technique was first employed to study the electrochemical oxidation of $\mathrm{AA}$ on $\mathrm{IrO}_{\mathrm{x}} / \mathrm{GC}$ and bare $\mathrm{GC}$ electrode in PBS, pH 7.0 (Fig. 3A). The electrooxidation of AA was shown in the form of peak shaped differential pulse voltammogram with maximum current intensity at $0.25 \mathrm{~V}$ on bare GC (black curve) and at $0.025 \mathrm{~V}$ (red curve) on modified $\mathrm{IrO}_{\mathrm{x}} / \mathrm{GC}$ electrode, respectively. The modified electrode possesses a better sensitivity and selectivity in comparison to the bare $\mathrm{GC}$ - the oxidation peak potential
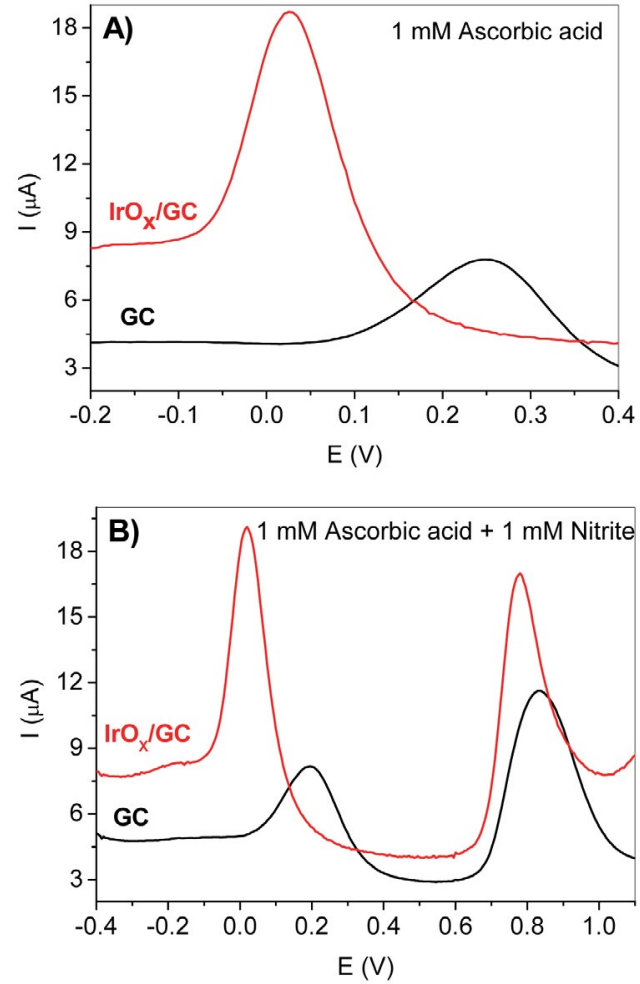

Fig. 3. A) DPV response of modified electrode $\mathrm{IrO}_{\mathrm{x}} / \mathrm{GC}$ for $1 \mathrm{mM}$ ascorbic acid in PBS (pH 7.0); B) Simultaneous DPV response of $\mathrm{IrO}_{\mathrm{x}} / \mathrm{GC}$ for a mixture of ascorbic acid $(1 \mathrm{mM})$ and nitrite $(1 \mathrm{mM})$ in PBS ( $\mathrm{pH} 7.0)$. of ascorbic acid at the modified electrode is significantly shifted (by $\sim 0.225 \mathrm{~V}$ ) in the negative direction compared with the bare GC, and 2.5-fold increase in the peak current at the modified $\mathrm{IrO}_{\mathrm{x}} / \mathrm{GC}$ was observed. The oxidation potential value $(0.025 \mathrm{~V})$ is significantly lower than the AA oxidation potential reported in previous research articles. ${ }^{40,45-51}$ The results indicate that the presented modified electrode is distinguished by a higher efficiency in the selective detection of ascorbic acid compared to other electrocalysts.

The possibility of the modified electrode for simultaneous detection of AA and nitrite was next examined. In buffer solution, that contains $1 \mathrm{mM}$ AA and $1 \mathrm{mM}$ nitrite, DPV response of the modified electrode $\mathrm{IrO}_{\mathrm{x}} / \mathrm{GC}$ shows two well-defined and well-separated oxidation peak current responses as presented in Fig. 3B. It is obvious that the oxidation potential of $\mathrm{AA}$ is much more negative than those of nitrite $(0.77 \mathrm{~V})$. The peak separation is about $0.745 \mathrm{~V}$ between AA and nitrite, implying it is feasible to detect nitrite in the presence of AA by DPV with the $\mathrm{IrO}_{\mathrm{x}} /$ GC electrode.

Fig. $4 \mathrm{~A}$ shows the DPV curves obtained at the $\mathrm{IrO}_{\mathrm{x}} /$ GC when the concentration of AA is changed (peak 1) while the concentration of nitrite kept constant (peak 2). The peak current associated with the oxidation of AA is increased linearly with the increase in AA concentration,
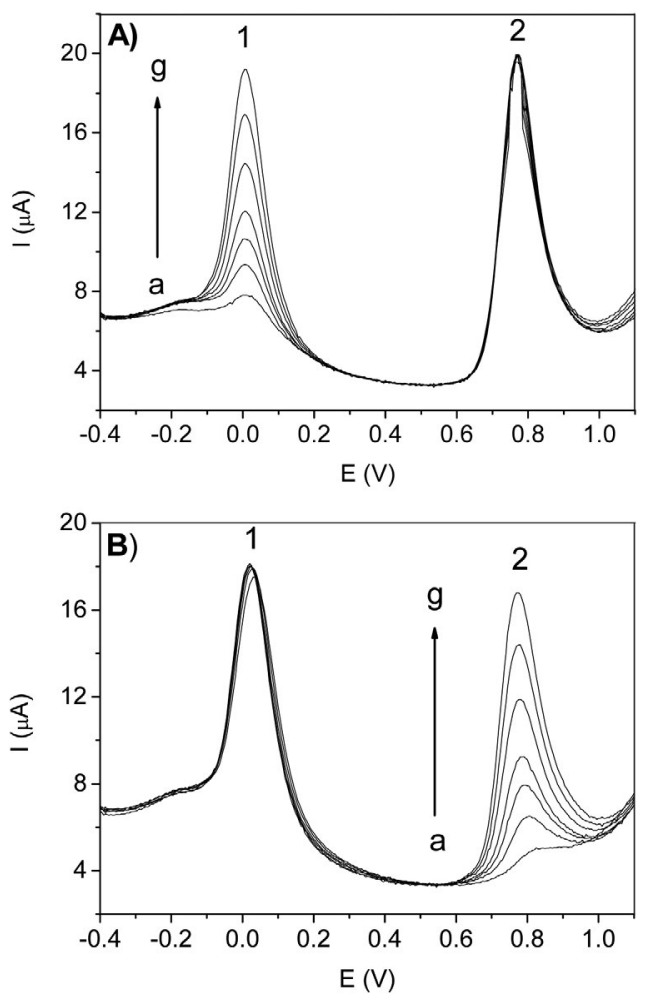

Fig. 4. DPVs response of $\mathrm{IrO}_{\mathrm{x}} / \mathrm{GC}$ in $\mathrm{PBS}$ (pH 7.0) containing: A) 1 $\mathrm{mM}$ nitrite (peak 2) in the presence of different concentrations of AA (peak 1); B) $1 \mathrm{mM} \mathrm{AA}$ (peak 1) in the presence of different concentrations of nitrite (peak 2). Concentrations (in $\mathrm{mM}$ ) as follows: (a) 0.1 , (b) 0.2 , (c) 0.3 , (d) 0.4, (e) 0.6 , (f) 0.8 and (g) 1.0 . 
while the peak height of nitrite remains stable. The observed phenomenon clearly shows that it is possible to detect selectively AA concentration in the presence of nitrite ions. An analogous analytical test was also carried out at a constant concentration of AA and varying concentration of nitrite (Fig 4B). The obtained results prove that the modified electrode possesses the ability to detect single species separately or to determine the specific concentrations of mixtures of the two species.

\section{2. 1. Voltammetric and Amperometric Detection of Nitrite}

The DPV curves of the bare GC and of the $\mathrm{IrO}_{\mathrm{x}} / \mathrm{GC}$ electrode (Fig. 3B) clearly show that the modified electrode exhibits higher electrocatalytic activity towards nitrite oxidation. In the presence of nitrite the higher peak current and shift towards lower potential indicate better catalytic behaviour of the modified electrode.

Fig. 5 presents the DPV curves of nitrite with different concentrations $(0.2-3.1 \mathrm{mM})$. The peak current was proportional to the nitrite concentration and it can be expressed in a model such as: $y=a x+b$, where $a$ is the slope of the calibration curve in terms of sensitivity. The linear regression equation was as follows: $\mathrm{I}_{\mathrm{p}}(\mu \mathrm{A})=9.419 \mathrm{C}(\mathrm{mM})$ +0.397 and was accomplished with a correlation coefficient of 0.998 (Fig. 4, inset). The proposed electrode shows good electrochemical sensitivity of $133.2 \mu \mathrm{A} \mathrm{mM} \mathrm{mm}^{-1} \mathrm{~cm}^{-2}$ (normalized to the electrode geometric surface area) up to $3.1 \mathrm{mM}$ nitrite.

The reproducibility of the current response of the modified electrode is essential for its successful application as a sensing element in construction of electrochemical sensor systems. In this connection, the reproducibility of the DPV current of $\mathrm{IrO}_{\mathrm{x}} / \mathrm{GC}$ to $0.6 \mathrm{mM}$ and $1.2 \mathrm{mM}$ nitrite was examined. For 10 successive independent measurements in presence of $0.6 \mathrm{mM}$ nitrite the electrode response was $6.099 \pm 0.064 \mu \mathrm{A}$ and the relative standard deviation (RSD) was calculated to be $1.05 \%$. Analogous studies car-

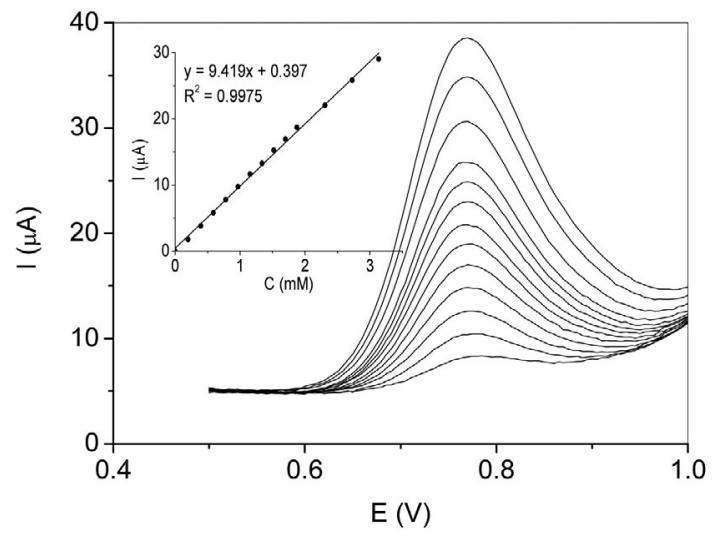

Fig. 5. DPVs of modified electrode $\mathrm{IrO}_{\mathrm{X}} / \mathrm{GC}$ in the presence of various concentrations of nitrite in PBS ( $\mathrm{pH}$ 7.0). Inset: linear relationship between the peak current and the concentration. ried out in presence of $1.2 \mathrm{mM}$ nitrite show electrode response of $11.659 \pm 0.114 \mu \mathrm{A}$ and RSD of $0.98 \%$. The results prove that the modified electrode possesses excellent reproducibility of the current signal.

Selectivity plays a vital role in practical use of sensors. In order to study the selectivity of the modified electrode, the interference effect of various species (in concentrations 10 times that of nitrite): $\mathrm{Cl}^{-}, \mathrm{Br}^{-}, \mathrm{CO}_{3}{ }^{2-}, \mathrm{NO}_{3}{ }^{-}$, $\mathrm{SO}_{4}{ }^{2-}, \mathrm{BrO}_{3}{ }^{-}, \mathrm{CH}_{3} \mathrm{COO}^{-}, \mathrm{Mg}^{2+}, \mathrm{Cu}^{2+}$, glucose and sodium citrate, was examined during DPV current response for $\mathrm{NO}_{2}^{-}$, performing an independent DPV measurement for each substance, respectively. The response current increased about $6.8 \%$ when $\mathrm{Br}^{-}$was injected into the buffer solution, suggesting this anion might have a moderate interference in the detection of nitrite. In the other experiments, no obvious interference was observed - the changes in current response on the modified electrode keep within $5 \%$ in the presence of $10 \mathrm{mM} \mathrm{Cl}^{-}, \mathrm{CO}_{3}{ }^{2-}, \mathrm{NO}_{3}{ }^{-}$, $\mathrm{SO}_{4}{ }^{2-}, \mathrm{BrO}_{3}{ }^{-}, \mathrm{CH}_{3} \mathrm{COO}^{-}, \mathrm{Mg}^{2+}, \mathrm{Cu}^{2+}$, glucose and sodium citrate in $1 \mathrm{mM}$ nitrite solution, indicating that they have negligible interference for nitrite detection (Table 1).

Table 1. Changes in DPV current response on the modified electrode in the presence of several inorganic and organic compounds (10 $\mathrm{mM}$ of each interferent) in $1 \mathrm{mM}$ nitrite solution.

\begin{tabular}{lcc}
\hline Interferent & Signal change (\%) & Interference \\
\hline $\mathrm{NaCl}$ & -2.6 & Negligible \\
$\mathrm{KBr}$ & +6.8 & Moderate \\
$\mathrm{MgCl}_{2}$ & -3.6 & Negligible \\
$\mathrm{Na}_{2} \mathrm{CO}_{3}$ & -0.96 & Negligible \\
$\mathrm{NaNO}_{3}$ & -1.2 & Negligible \\
$\mathrm{CuSO}_{4}$ & -0.66 & Negligible \\
$\mathrm{KBrO}_{3}$ & +4.4 & Negligible \\
$\mathrm{NaOOCCH}_{3}$ & -0.55 & Negligible \\
$\mathrm{C}_{6} \mathrm{H}_{12} \mathrm{O}_{6}$ & -0.32 & Negligible \\
$\mathrm{Na}_{3} \mathrm{C}_{6} \mathrm{H}_{5} \mathrm{O}_{7}$ & -1.3 & Negligible \\
\hline
\end{tabular}

The amperometric response was evaluated for the modified electrode with the successive additions of nitrite at a fixed potential. Fig. 6 displays the authentic record of the amperometric response of $\mathrm{IrO}_{\mathrm{x}} / \mathrm{GC}$ to successive additions (in $30 \mathrm{~s}$ intervals) of $\mathrm{NO}_{2}{ }^{-}$stock solution at a constant applied potential of $0.77 \mathrm{~V}$ under constant stirring. A remarkable increase and a fast response of the amperometric current were observed. Upon addition of nitrite the modified electrode shows increasing staircase current response, corresponding to the electrochemical oxidation of the analyte, which evidences that $\mathrm{IrO}_{\mathrm{x}} / \mathrm{GC}$ efficiently promoted the electrooxidation of nitrite. Steady-state current value was reached within $5 \mathrm{~s}$.

The background subtracted steady-state response of the electrode (Fig. 6, inset) was proportional to the nitrite concentration up to $10 \mathrm{mM}$ (correlation coefficient of 0.989 ) with a sensitivity of $11.294 \mu \mathrm{A} \mathrm{mM}^{-1}$ (or $159.7 \mu \mathrm{A}$ $\mathrm{mM}^{-1} \mathrm{~cm}^{-2}$ ), calculated on the basis of 49 points. The lim- 


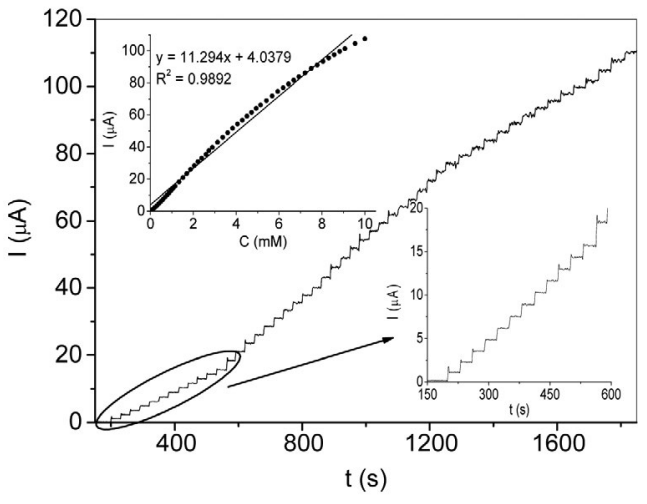

Fig. 6. Amperometric response of modified electrode $\mathrm{IrO}_{\mathrm{x}} / \mathrm{GC}$ in PBS ( $\mathrm{pH} 7.0$ ) for successive additions of nitrite at potential of $0.77 \mathrm{~V}$. Inset: the enlarged initial section of the amperometric curve (12 injections of $0.1 \mathrm{mM} \mathrm{NO}_{2}{ }^{-}$and 1 injection of $0.2 \mathrm{mM} \mathrm{NO}_{2}{ }^{-}$were added) and the corresponding calibration plot.

it of detection is $0.63 \mu \mathrm{M}$ (defined at a signal-to-noise ratio of 3), which is lower than the drinking water limit quantity postulated by the WHO $(4.3 \mu \mathrm{M}) .^{2}$

The selectivity of the modified electrode for nitrite was also confirmed by amperometric measurements. For interference test, we used the same common interfering ions and organic substances as reported for our DPV experiments. Amperometric response of $\mathrm{IrO}_{\mathrm{x}} / \mathrm{GC}$ towards the additions of these substances, followed by nitrite addition, were examined at a constant potential of $0.77 \mathrm{~V}$. Fig. 7 shows the authentic response of electrode $\mathrm{IrO}_{\mathrm{x}} / \mathrm{GC}$ for the interval (in $25 \mathrm{~s}$ ) additions of $0.35 \mathrm{mM}$ nitrite and a 10 -fold concentration of the above mentioned interfering substances. The amperometric record clearly shows that the tested species had no effect on the quantitative nitrite detection. No response was observed for modified electrode in the presence of interfering substances and the electrode response for nitrite after adding interfering substances was not changed. The results reveal the application potential of the modified electrode $\mathrm{IrO}_{\mathrm{x}} / \mathrm{GC}$ for precise sensing of nitrite in real samples.

The comparison of sensing performance based on different electrochemical methods and modified materials for the detection of nitrite in previous reports was shown in Table 2. We have summarized various nitrite sensors with respect to the working potential, sensitivity, linearity, detection limit and the reproducibility of the signal. From the data presented it can be seen that the proposed $\mathrm{IrO}_{\mathrm{x}}$-modified glassy carbon electrode possesses superior reproducibility of the current response. It is found that the

Table 2. Comparison of the proposed $\mathrm{IrO}_{\mathrm{x}} / \mathrm{GC}$ with other reported sensors for determination of nitrite.

\begin{tabular}{|c|c|c|c|c|c|c|}
\hline Sensing electrode ${ }^{a}$ & Technique $^{b}$ & $\begin{array}{l}\text { E, } \\
\text { V }\end{array}$ & 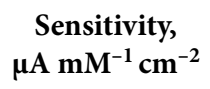 & $\begin{array}{c}\text { Linear range, } \\
\mu \mathrm{M}\end{array}$ & $\begin{array}{l}\text { Detection } \\
\text { limit, } \mu M\end{array}$ & $\begin{array}{c}\text { RSD, } \\
\%\end{array}$ \\
\hline p-NiTAPc/GC 56 & DPA & $0.82^{c}$ & - & $0.5-8000$ & 0.1 & $2.8(\mathrm{n}=12)$ \\
\hline $\mathrm{CDP} / \mathrm{GS} / \mathrm{MWCNTs} / \mathrm{GC}^{19}$ & $\mathrm{CV}$ & $0.7^{\mathrm{c}}$ & $12.68^{\mathrm{e}}$ & $5-6750$ & 1.65 & $3.7(\mathrm{n}=5)$ \\
\hline $\mathrm{Hb} / \mathrm{PLE}^{57}$ & DPV & $-0.8^{\mathrm{c}}$ & $2.164^{\mathrm{g}}$ & $10-220$ & 5.0 & $2.0(\mathrm{n}=3)$ \\
\hline Nano-Pt/P3MT/GC 24 & DPV & $0.78^{\mathrm{d}}$ & 222.82 & $8-1700$ & 1.5 & $3.4(\mathrm{n}=10)$ \\
\hline Thionine/ACNTs/GC 58 & DPV & $0.8^{\mathrm{d}}$ & - & $3-500$ & 1.12 & $2.75(\mathrm{n}=5)$ \\
\hline AgPs-IL-CPE 29 & SWV & - & - & $50-1000$ & 3.0 & $0.3(\mathrm{n}=7)$ \\
\hline EAG/SPCE ${ }^{59}$ & Amp & $0.8^{\mathrm{d}}$ & 126 & $0.1-16400$ & 0.038 & $1.4(\mathrm{n}=5)$ \\
\hline GR/Ppy/CS/GC ${ }^{20}$ & Amp & $0.9^{c}$ & $40.0^{\mathrm{e}}$ & $0.5-722$ & 0.1 & $1.8(\mathrm{n}=10)$ \\
\hline Poly-TBO-SWCNT/GC 21 & Amp & $0.92^{\mathrm{d}}$ & $84.3^{\mathrm{e}}$ & $1-4000$ & 0.37 & - \\
\hline Nano-Au/P3MT/GC 60 & Amp & $0.78^{\mathrm{c}}$ & - & $10-1000$ & 2.3 & $3.0(\mathrm{n}=10)$ \\
\hline $\mathrm{PAOA} / \mathrm{GC}^{61}$ & Amp & $1.0^{c}$ & 64.3 & $5-2000$ & 2.0 & $1.2(\mathrm{n}=6)$ \\
\hline $\mathrm{CoHCF} / \mathrm{CPE}^{27}$ & Amp & $0.92^{\mathrm{d}}$ & $11.11^{\mathrm{e}}$ & $100-2150$ & 1.19 & 3.27 \\
\hline CR-GO/GC 39 & Amp & $0.8^{\mathrm{d}}$ & $0.0267^{f}$ & $8.9-167$ & 1.0 & $2.29(\mathrm{n}=4)$ \\
\hline MWCNTs/MB paper 38 & Amp & $0.83^{\mathrm{d}}$ & 400 & $12-2500$ & 3.6 & - \\
\hline PANI- $\mathrm{MoS}_{2} / \mathrm{GC}^{22}$ & Amp & $0.9^{c}$ & 28.68 & $4-4834$ & 1.5 & - \\
\hline Fe-HNPs/GC 33 & Amp & $0.73^{c}$ & $19.83^{\mathrm{e}}$ & $9-3000$ & 2.6 & 0.7 \\
\hline AgNPs/GC ${ }^{34}$ & Amp & $0.82^{\mathrm{c}}$ & - & $10-1000$ & 1.2 & - \\
\hline ZnO@rFGO/GC 35 & Amp & $0.9^{\mathrm{d}}$ & - & $10-5000$ & 41 & - \\
\hline AuNPs/SG/GC 62 & Amp & $0.73^{c}$ & $45.44^{\mathrm{e}}$ & $10-3960$ & 0.2 & $1.92(\mathrm{n}=8)$ \\
\hline \multirow{2}{*}{$\mathrm{IrO}_{\mathrm{X}} / \mathrm{GC}^{\text {This work }}$} & DPV & \multirow{2}{*}{$0.77^{\mathrm{d}}$} & 133.2 & $10-3100$ & 0.63 & $2.6(\mathrm{n}=5)$ \\
\hline & Amp & & 159.7 & $2-10000$ & 5 & $1.05(\mathrm{n}=10)$ \\
\hline
\end{tabular}

${ }^{\mathrm{a}} \mathrm{GC}$ - glassy carbon; SPCE - screen printed carbon electrode; CPE - carbon paste electrode; NPs - nanoparticles; MWCNTs - multiwall carbon nanotubes, SWCNTs - singlewall carbon nanotubes; p-NiTAPc - polymeric nikel tetraaminothphalocyanine; CDP/GS - poly-cyclodextrin/ graphene; $\mathrm{Hb}$ - hemoglobin; PLE - pencil lead electrode; EAG - electrochemically activated graphite; ACNTs - aligned carbon nanotubes; GR/PPy/ CS - graphene/polypyrrole/chitosan; TBO - Toluidine Blue O; P3MT - poly(3-methylthiophene); PAOA - poly(aniline-co-o-aminophenol); $\mathrm{CoHCF}$ - cobalt hexacyanoferrate; CR-GO - chemically reduced graphene oxide; MB - methylene blue; PANI - polyaniline; IL - ionic liquid; FeHNPs - hollow hematite nano-polyhedrons; $\mathrm{rFGO}$ - reduced functionalized graphene oxide; ${ }^{\mathrm{b}} \mathrm{DPA}$ - differential pulse amperometry; CV - cyclic voltammetry; DPV - differential pulse voltammetry; SWV - square wave voltammetry; Amp - amperometry; ${ }^{c}$ Reference electrode: saturated

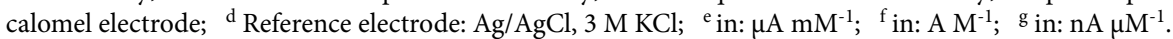




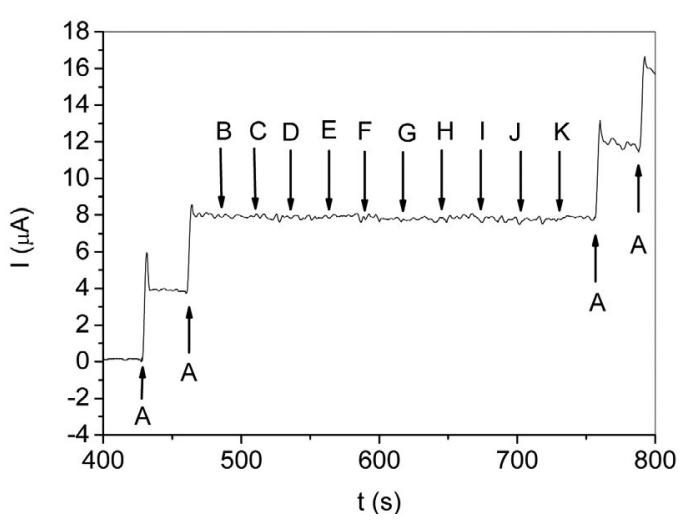

Fig. 7. Amperometric $i$ - $t$ curve of modified electrode $\mathrm{IrO}_{\mathrm{x}} / \mathrm{GC}$ for the determination of $0.35 \mathrm{mM} \mathrm{NO}_{2}^{-}(\mathrm{A})$ in the presence of $3.5 \mathrm{mM}$ of different interfering species (B) $\mathrm{CH}_{3} \mathrm{COO}^{-}$, (C) $\mathrm{Cl}^{-}$, (D) $\mathrm{Br}^{-}$, (E) $\mathrm{CO}_{3}{ }^{2-}$, (F) citrate, (G) $\mathrm{BrO}_{3}{ }^{-}$, (H) $\mathrm{NO}_{3}{ }^{-}$, (I) $\mathrm{SO}_{4}{ }^{2-}$, (J) glucose and (K) $\mathrm{Mg}^{2+}$, added one by one with an interval of $25 \mathrm{~s}$ to $0.1 \mathrm{M}$ PBS ( $\mathrm{pH} 7.0)$ at an applied potential of $0.77 \mathrm{~V}$.

developed electrocatalyst is more preferable than a number of other electrode-catalysts, employed as nitrite sensors, in one or more categories, particularly because of the lower working potential, higher sensitivity and wider linear range.

\section{2. 2. Voltammetric and Amperometric Detection of Ascorbic Acid}

The analytical parameters of the modified electrode $\mathrm{IrO}_{\mathrm{x}} / \mathrm{GC}$ for AA quantitative detection also were studied in detail. A clear increase in DPV peak current was observed upon increasing the concentration of AA and the peak current was found to increase linearly as a function of the concentration up to $1.9 \mathrm{mM}$ with a correlation coefficient of 0.999 (Fig. 8, Inset). The sensitivity calculated from the slope of the regression line was 9.55 $\mu \mathrm{A} \mathrm{mM} \mathrm{m}^{-1}\left(135 \mu \mathrm{A} \mathrm{mM}^{-1} \mathrm{~cm}^{-2}\right)$. Measurements $(\mathrm{n}=10)$ done with the presented modified electrode in presence of $1 \mathrm{mM}$ AA showed current signal of $9.256 \pm 0.084 \mu \mathrm{A}$

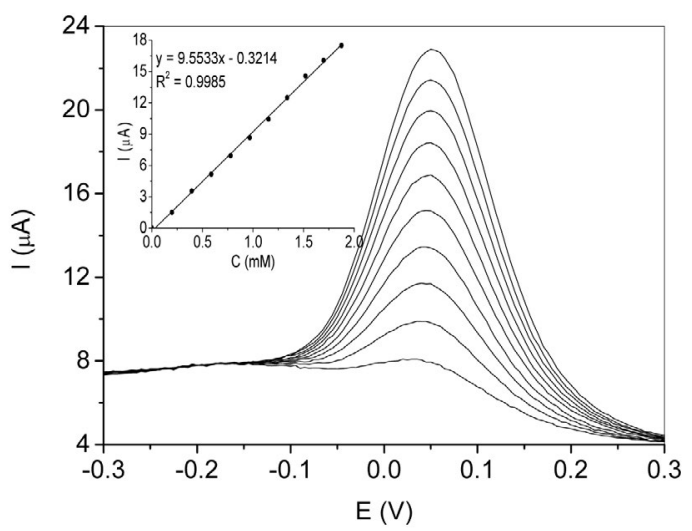

Fig. 8. DPVs of modified electrode $\mathrm{IrO}_{\mathrm{x}} / \mathrm{GC}$ in the presence of various concentrations of AA in PBS ( $\mathrm{pH}$ 7.0). Inset: linear relationship between the peak current and the concentration. featuring extremely high reproducibility (RSD equal to $0.91 \%)$.

Fig. 9 displays the current-time response of the modified electrode recorded after successive additions of 0.1 and $0.2 \mathrm{mM}$ AA into magnetically stirred $\mathrm{PBS}(\mathrm{pH} 7.0)$ at an applied potential of $0.025 \mathrm{~V}$. The electrode reaction is fast in reaching a dynamic equilibrium upon each addition of AA and the response time was $5 \mathrm{~s}$. The calibration plot corresponding to the amperometric current response is illustrated as an Inset of the same figure. The sensitivity was $96.2 \mu \mathrm{A} \mathrm{mM}^{-1} \mathrm{~cm}^{-2}$ and the linear response was proportional to the AA concentration in the range from 0.01 to 3 $\mathrm{mM}$ (0.994), being wider than those reported for other modified electrodes. ${ }^{44,46,48-51}$ The merits of the presented modified electrode $\mathrm{IrO}_{\mathrm{x}} / \mathrm{GC}$ can be evaluated by the comparative review presented in Table 3 . As can be seen, the $\mathrm{IrO}_{\mathrm{x}} / \mathrm{GC}$ exhibits comparable or better analytical performance than other published electrochemical sensors for AA detection.

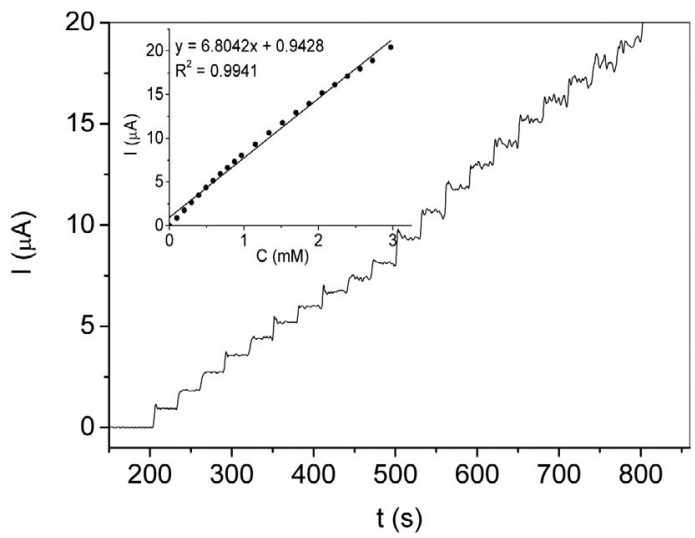

Fig. 9. Amperometric response of modified electrode $\mathrm{IrO}_{\mathrm{X}} / \mathrm{GC}$ in PBS (pH 7.0) for successive additions of AA at an applied potential of $0.025 \mathrm{~V}$. Inset: calibration plot of chronoamperometric currents vs. AA concentration.

Several forms of inorganic and organic interference were tested to determine whether they could affect the detection of AA with the modified electrode. These interferences were investigated in $0.1 \mathrm{M}$ PBS ( $\mathrm{pH}$ 7.0) containing $0.5 \mathrm{mM} \mathrm{AA}$ at constant potential of $0.025 \mathrm{~V}$. The results showed that concentrations of $3 \mathrm{mM} \mathrm{NaCl}, \mathrm{KI}, \mathrm{KBr}$, $\mathrm{Na}_{2} \mathrm{CO}_{3}, \mathrm{MgCl}_{2}, \mathrm{NaOOCCH}_{3}$, sodium citrate and glucose did not influence the current signal, confirming the high selectivity of $\mathrm{IrO}_{\mathrm{x}} / \mathrm{GC}$ in AA quantitative determination.

Since long-term stability is crucial factor when the modified material is used in sensor system, the developed electrode $\mathrm{IrO}_{\mathrm{x}} / \mathrm{GC}$ was stored at room temperature and measured every 4 days. After 20 days storage the current response to $1 \mathrm{mM}$ nitrite (measured by constant potential amperometry at $0.77 \mathrm{~V}$ ) retained $94 \%$ of the initial value, demonstrating the good stability of the electrodeposited catalytic active phase. 
Table 3. Comparison of the proposed $\mathrm{IrO}_{\mathrm{x}} / \mathrm{GC}$ with other reported sensors for determination of ascorbic acid.

\begin{tabular}{|c|c|c|c|c|c|c|}
\hline Sensing electrode ${ }^{a}$ & Technique & $\begin{array}{l}\text { E, } \\
\text { V }\end{array}$ & $\begin{array}{c}\text { Sensitivity, } \\
\mu \mathrm{A} \mathrm{mM}^{-1} \mathrm{~cm}^{-2}\end{array}$ & $\begin{array}{c}\text { Linear range, } \\
\mu \mathrm{M}\end{array}$ & $\begin{array}{l}\text { Detection } \\
\text { limit, } \mu M\end{array}$ & $\begin{array}{c}\text { RSD, } \\
\%\end{array}$ \\
\hline pdon/CNTs/GC ${ }^{44}$ & Amp & $-0.1^{\mathrm{c}}$ & $2.1^{\mathrm{e}}$ & $2-1000$ & 0.8 & $4.8(n=5)$ \\
\hline GDSP/CPE ${ }^{45}$ & Amp & $0.4^{\mathrm{c}}$ & $21.879^{e}$ & $150-8000$ & 3.375 & - \\
\hline EMGON/CPE ${ }^{46}$ & Amp & $0.38^{\mathrm{c}}$ & $78.63^{e}$ & up to 1000 & 1.54 & $1.15(\mathrm{n}=15)$ \\
\hline Q-chitosan/C $\mathrm{C}^{40}$ & Amp & $0.1^{\mathrm{d}}$ & 76 & $10-5000$ & 3 & - \\
\hline $\mathrm{Au}-\mathrm{PANI} / \mathrm{GC}^{47}$ & Amp & $-0.2^{\mathrm{h}}$ & 25.69 & $10-12000$ & 8.2 & $5.9(\mathrm{n}=3)$ \\
\hline $\mathrm{Au} / \mathrm{EPA} / \mathrm{CPE}^{48}$ & Amp & $0.3^{\mathrm{d}}$ & $21.7^{\mathrm{e}}$ & $50-750$ & 2.75 & $2.23(\mathrm{n}=3)$ \\
\hline CoTNPPcMWCNTs/GC ${ }^{49}$ & Amp & $0.215^{\mathrm{c}}$ & - & $10-1600$ & 5 & - \\
\hline AuNPs/GO/GC ${ }^{50}$ & Amp & $0.15^{\mathrm{d}}$ & 101.86 & $0.11-600$ & 0.11 & - \\
\hline PEDOT/CPE ${ }^{51}$ & $\mathrm{CV}$ & $0.29^{\mathrm{d}}$ & $12.3^{\mathrm{e}}$ & $50-3000$ & - & - \\
\hline \multirow{2}{*}{$\mathrm{IrO}_{\mathrm{x}} / \mathrm{GC}^{\text {This work }}$} & DPV & \multirow{2}{*}{$0.025^{\mathrm{d}}$} & 135 & $50-1900$ & 10 & $0.91(\mathrm{n}=10)$ \\
\hline & Amp & & 96.2 & $10-3000$ & 4 & $3.2(\mathrm{n}=5)$ \\
\hline
\end{tabular}

${ }^{a}$ pdon - 1,10-phenenthroline-5,6-dione; GDSP - gold decorated $\mathrm{SiO}_{2} @$ polyaniline (PANI) core-shell microspheres; EMGON - electroactive mesoporous gold-organosilica nanocomposite; Q-chitosan - hydroquinone modified chitosan; Au/EPA - gold/aniline-pentamer-based electroactive polyamide; CoTNPPc - cobalt(II) tetra-neopentyloxy phthalocyanine; ${ }^{\mathrm{h}}$ Reference electrode: saturated mercurous sulfate electrode (SMSE).

Other abbreviations are the same as Table 2 .

\section{Conclusion}

In summary, applying simple and rapid two-step procedure for electrodeposition of iridium oxide onto glassy carbon, a new type modified electrode $\mathrm{IrO}_{\mathrm{x}} / \mathrm{GC}$ was developed. DPV experiments indicated that the $\mathrm{IrO}_{\mathrm{x}} / \mathrm{GC}$ possesses excellent electrocatalytic activity towards the oxidation of both nitrite and AA. The proposed modified electrode-catalyst, studied by DPV and constant potential amperometry, exhibits remarkable analytical characteristics for its use in nitrite and AA sensing applications wide linear range, high sensitivity, good selectivity, fast and stable amperometric response with excellent reproducibility and long-term stability. The sensor performances were unaffected by the presence of variety of inorganic and organic interferences make it a promising sensing material for sensitive and selective nonenzymatic quantitative detection of nitrite and AA.

\section{References}

1. R. Pegg, F. Shahidi: Nitrite Curing of Meat. Food \& Nutrition Press Inc., Trumbull, CT, USA, 2008, pp. 1-268.

https://onlinelibrary.wiley.com/doi/abs/10.1002/ 9780470385081.ch1

2. World Health Organization, Guidelines for Drinking-Water Quality: Fourth Edition Incorporating the First Addendum, WHO, Geneva, 2017, ISBN-13: 978-92-4-154995-0 https://www.ncbi.nlm.nih.gov/books/NBK442376/

3. P. Rastogi, V. Ganesan, S. Krishnamoorthi, J. Mater. Chem. A 2014, 2, 933-943. DOI:10.1039/C3TA13794E

4. E. Beamonte, J. Bermudez, A. Casino, J. Environ. Manag. 2007, 83, 307-314. DOI:10.1016/j.jenvman.2006.03.010

5. D. Zhang, H. Ma, Y. Chen, H. Pang, Y. Yu, Anal. Chim. Acta 2013, 792, 35-44. DOI:10.1016/j.aca.2013.07.010
6. R. Jiang, D. Paik, J. Hankinson, R. Barr, Am. J. Respir. Crit. Care Med. 2007, 175, 798-804.

DOI:10.1164/rccm.200607-969OC

7. T. Chan, Toxicol. Lett. 2011, 200, 107-108. DOI:10.1016/j.toxlet.2010.11.002

8. P. Jakszyn, C. Gonzalez, World J. Gastroenterol. 2006, 12, 42964303. https:/www.ncbi.nlm.nih.gov/pubmed/16865769

9. P. Erkekoglu, H. Sipahi, T. Baydar, Food Anal. Meth. 2009, 2, 61-65. DOI:10.1007/s12161-008-9045-0

10. K. Lenghartova, L. Lauko, F. Cacho, E. Beinrohr, Acta Chim. Slov. 2015, 62, 152-158. DOI:10.17344/acsi.2014.838

11. H. Filik, D. Giray, B. Ceylan, R. Apak, Talanta 2011, 85, 18181824. DOI:10.1016/j.talantwwwa.2011.07.052

12. Z. Lin, X. Dou, H. Li, Y. Ma, J. Lin, Talanta 2015, 132, 457462. DOI:10.1016/j.talanta.2014.09.046

13. X. Wang, E. Adams, A. Van Schepdael, Talanta 2012, 97, 142 144. DOI:10.1016/j.talanta.2012.04.008

14. W. Jobgen, S. Jobgen, H. Li, C. Meininger, G. Wu, J. Chromatogr. B 2007, 851, 71-82. DOI:10.1016/j.jchromb.2006.07.018

15. G. Xu, G. Xu, M. Xu, Z. Zhang, Y. Tian, H. Choi, W. Lee, Bull. Korean Chem. Soc. 2012, 33, 415-419.

DOI:10.5012/bkcs.2012.33.2.415

16. L. Chen, X. Liu, C. Wang, S. Lv, C. Chen, Microchim. Acta 2017, 184, 2073-2079. DOI:10.1007/s00604-017-2189-0

17. J. Dai, D. Deng, Y. Yuan, J. Zhang, F. Deng, S. He, Microchim. Acta 2016, 183, 1553-1561.

DOI:10.1007/s00604-016-1773-z

18. C. Yang, Q. Lu, S. Hu, Electroanalysis 2006, 18, 2188-2193. DOI:10.1002/elan.200603646

19. Y. Zhang, R. Yuan, Y. Chai, W. Li, X. Zhong, H. Zhong, Biosens. Bioelectron. 2011, 26, 3977-3980.

DOI:10.1016/j.bios.2011.03.017

20. D. Ye, L. Luo, Y. Ding, Q. Chen, X. Liu, Analyst 2011, 136, 4563-4569. DOI:10.1039/C1AN15486A

21. D. Gligor, A. Walcarius, J. Solid State Electrochem. 2014, 18, 1519-1528. DOI:10.1007/s10008-013-2365-Z 
22. Y. Zhang, P. Chen, F. Wen, C. Huang, H. Wang, Ionics 2016, 22, 1095-1102. DOI:10.1007/s11581-015-1634-5

23. K. Promsuwan, P. Thavarungkul, P. Kanatharana, W. Limbut, Electrochim. Acta 2017, 232, 357-369. DOI:10.1016/j.electacta.2017.02.138

24. Y. Zhou, H. Xian, F. Li, S. Wu, Q. Lu, Y. Li, L. Wang, Electrochim. Acta 2010, 55, 5905-5910. http://dx.doi:10.1016/j. electacta.2010.05.043

25. D. Zhang, H. Ma, Y. Chen, H. Pang, Y. Yu, Anal.Chim. Acta 2013, 792, 35-44. DOI:10.1016/j.aca.2013.07.010

26. R. Hallaj, A. Salimi, B. Kavosi, G. Mansouri, Sens. Actuat. B 2016, 233, 107-119. DOI:10.1016/j.snb.2016.04.028

27. H. Heli, I. Eskandari, N. Sattarahmady, A. Moosavi-Movahedi, Electrochim. Acta 2012, 77, 294-301. DOI:10.1016/j.electacta.2012.06.014

28. C. Kung, T. Chang, L. Chou, J. Hupp, O. Farha, K. Ho, Electrochem. Commun. 2015, 51, 2414-2417. DOI:10.1039/C4CC09272D

29. E. Menart, V. Jovanovski, S. B. Hočevar, Electrochem. Commun. 2015, 52, 45-48.

DOI:10.1016/j.elecom.2015.01.017

30. P. K. Sonkar, V. Ganesan, J. Solid State Electrochem. 2015, 19, 2107-2115. DOI:10.1007/s10008-014-2725-3

31. L. Zhang, F. Yuan, X. Zhang, L. Yang, Chem. Centr. J. 2011, 5, 75-84. DOI:10.1186/1752-153X-5-75

32. Y. Liu, J. Zhou, J. Gong, W. Wu, N. Bao, Z. Pan, H. Gu, Electrochim. Acta 2013, 111, 876-887.

DOI:10.1016/j.electacta.2013.08.077

33. C. Xia, X. Yanjun, W. Ning, Electrochim. Acta 2012, 59, 81-85. DOI:10.1016/j.electacta.2011.10.039

34. Z. Wang, F. Liao, T. Guo, S. Yang, C. Zeng, J. Electroanal. Chem. 2012, 664, 135-138.

DOI:10.1016/j.jelechem.2011.11.006

35. A. Marlinda, A. Pandikumar, N. Yusoff, N. Huang, H. Lim, Microchim. Acta 2014, 182, 1113-1122.

DOI:10.1007/s00604-014-1436-X

36. Q. Xie, W. He, S. Yu, X. Chen, X. Zhang, Y. Shen, Anal. Meth. 2014, 6, 7716-7721. DOI:10.1039/C4AY01461H

37. L. Zhou, J. Wang, L. Gai, D. Li, Y. Li, Sens. Actuat. B 2013, 181, 65-70. DOI:10.1016/j.snb.2013.02.041

38. T. Ömür, M. Alanyalığlu, Ionics 2017, 23, 3507-3516. DOI:10.1007/s11581-017-2142-6

39. V. Mani, A. Periasamy, S. Chen, Electrochem. Commun. 2012, 17, 75-78. DOI:10.1016/j.elecom.2012.02.009

40. H. Jirimali, R. Nagarale, D. Saravanakumar, J. Lee, W. Shin, Carbohydr. Pol. 2013, 92, 641-644.

DOI:10.1016/j.carbpol.2012.09.024

41. A. Pisoschi, A. Pop, A. Serban, C. Fafaneata, Electrochim. Acta 2014, 121, 443-460. DOI:10.1016/j.electacta.2013.12.127
42. T. Dodevska, E. Horozova, N. Dimcheva, Mat. Sci. Eng. B 2013, 178, 1497-1502. DOI:10.1016/j.mseb.2013.08.012

43. N. Dimcheva, T. Dodevska, E. Horozova, J. Electrochem. Soc. 2013, 160, 414-419. DOI:10.1149/2.025308jes

44. M. Wu, X. Mao, X. Li , X. Yang, L. Zhu, J. Electroanal. Chem. 2012, 682, 1-6. DOI:10.1016/j.jelechem.2012.06.007

45. C. Weng, Y. Chen, C. Chien, S. Hsu, Y. Jhuo, J. Yeh, C. Dai, Electrochim. Acta 2013, 95, 162-169.

DOI:10.1016/j.electacta.2013.01.150

46. C. Weng, P. Hsu, S. Hsu, C. Chang, W. Hung, P. Wu, J. Yeh, J. Mater. Chem. B 2013, 1, 4983-4991.

DOI:10.1039/C3TB20433B

47. H. Zhang, F. Huang, S. Xu, Y. Xia, W. Huang, Z. Li, Electrochem. Commun. 2013, 30, 46-50.

DOI:10.1016/j.elecom.2013.02.007

48. M. Tsai, S. Lu, Y. Lai, G. Lai, G. Dizon, T. Yang, Y. Lin, Y. Chou, eXPRESS Pol. Lett. 2018, 12, 71-81.

DOI:10.3144/expresspolymlett.2018.6

49. X. Zuo, N. Li, H. Zhang, J. Mater. Sci. 2012, 47, 2731-2735. DOI:10.1007/s10853-011-6099-y

50. J. Song, L. Xu, R. Xing, Q. Li, C. Zhou, D. Liu, H. Song, Sci. Rep. 2014, 4, 7515-7520. DOI:10.1038/srep07515

51. J. Sui, W. Li, Q. Pan, Int. J. Polym. Mater. 2016, 66, 258-264. DOI:10.1080/00914037.2016.1201826

52. A. Salimi, R. Hallaj, B. Kavosi, B. Hagighi, Anal. Chim. Acta 2010, 661, 28-34. DOI:10.1016/j.aca.2009.12.005

53. M. Roushani, M. Sarabaegi, J. Electroanal. Chem. 2014, 717, 147-152. DOI:10.1016/j.jelechem.2014.01.013

54. L. Preda, T. Kondo, T. Spataru, M. Matin, M. Radu, P. Osiceanu, A. Fujishima, N. Spataru, Chem. ElectroChem. 2017, 4, 1908-1915. DOI:10.1002/celc.201700155

55. Y. Lazarova, I. Shterev, T. Dodevska, Monatsh. Chem. 2018, 149, 1955-1962. DOI:10.1007/s00706-018-2275-y

56. Z. Wen, T. Kang, Talanta 2004, 62, 351-355. DOI:10.1016/j.talanta.2003.08.003

57. M. Majidi, A. Saadatirad, E. Alipour, Electroanalysis 2013, 25, 1-9. DOI:10.1002/elan.201300082

58. K. Zhao, H. Song, S. Zhuang, L. Dai, P. He, Y. Fang, Electrochem. Commun. 2007, 9, 65-70.

DOI:10.1016/j.elecom.2006.07.001

59. S. Palanisamy, C. Karuppiah, S. Chen, P. Periakaruppan, J. Electroanal.Chem. 2014, 727, 34-38.

DOI:10.1016/j.jelechem.2014.05.025

60. X. Huang, Y. Li, Y. Chen, L.Wang, Sens. Actuat. B 2008, 134, 780-786. DOI:10.1016/j.snb.2008.06.028

61. L. Liu, H. Cui, H. An, J. Zhai, Y. Pan, Ionics 2017, 23, 15171523. DOI:10.1007/s11581-017-1972-6

62. S. Li, G. Zhao, R. Zhang, Y. Hou, L. Liu, H. Pang, Microchim. Acta 2013, 180, 821-827. DOI:10.1007/s00604-013-0999-2 


\section{Povzetek}

Iridijev oksid $\left(\mathrm{IrO}_{\mathrm{x}}\right.$ ) smo z dvostopenjskim postopkom elektrodepozicije nanesli na elektrodo iz steklastega ogljika. Elektrokatalitične lastnosti modificirane elektrode iz steklastega ogljika $\mathrm{IrO}_{\mathrm{x}} / \mathrm{GC}$ so bile ovrednotene v primerih elektrokemijske oksidacije nitrita in askorbinske kisline. Razviti elektrodni katalizator smo preučevali z različnimi elektrokemijskimi metodami. Poskusi diferencialne pulzne voltametrije (DPV) so pokazali, da ima modificirana elektroda odlično elektrokatalitsko aktivnost pri oksidaciji nitrita in askorbinske kisline v nevtralnem mediju in omogoča tudi kvantitativno določevanje teh snovi. Izvedli smo tudi amperometrične meritve s konstantnim potencialom. Modificirana elektroda iz steklastega ogljika $\mathrm{IrO}_{\mathrm{x}} / \mathrm{GC}$ je pokazala občutlijivost na nitrit $\left(159,7 \mu \mathrm{A} \mathrm{mM}^{-1} \mathrm{~cm}^{-2}\right) \mathrm{v}$ širokem linearnem območju od 0,002 do $10 \mathrm{mM}$ pri 0,77 V (glede na $\mathrm{Ag} / \mathrm{AgCl}, 3 \mathrm{M} \mathrm{KCl}$ ) in na askorbinsko kislino $\left(96,2 \mu \mathrm{A} \mathrm{mM}-1 \mathrm{~cm}^{-2}\right) \mathrm{v}$ linearnem območju od 0,01 do $3 \mathrm{mM}$ pri $0,025 \mathrm{~V}$. Meja zaznavnosti je bila v primeru določevanja nitrita $0,63 \mu \mathrm{M} v$ primeru askorbinske kisline pa $4 \mu \mathrm{M}$; v obeh primerih je bil odziv elektrode hiter $(5 \mathrm{~s})$. Glede na preprost in hiter postopek elektrodepozicije za pripravo modificirane elektrode $\mathrm{IrO}_{\mathrm{x}} / \mathrm{GC}$ predstavlja le-ta nov elektrodni katalizator za občutljivo in selektivno kvantitativno detekcijo nitritov in askorbinske kisline. Širok linearni razpon, dobra selektivnost, ponovljivost amperometričnega odziva in dolgotrajna stabilnost modificirane elektrode $\mathrm{IrO}_{\mathrm{x}} / \mathrm{GC}$ so obetavne lastnosti novega materiala za senzorje, ki je primeren za kvantitativno detekcijo nitrita in askorbinske kisline. 